\title{
Jogando com Piratas e Ditadores: As representações sobre o Caribe nos videogames
}

\author{
Robson S. Bello ${ }^{1}$
}

Resumo: este artigo pretende iluminar a forma como o Caribe tem sido representado e simulado nos jogos eletrônicos (Videogames), a partir da década de 1980 até os dias atuais. Ainda que sejam caracterizados como uma das mídias mais bem sucedidas comercialmente, além de exercer forte influência cultural na construção de um imaginário histórico e cultural, os jogos eletrônicos ainda não são utilizados de forma ampla pelos historiadores, fazendo com que haja poucas pesquisas que considerem tais mídias como fontes. Temos como objetivo, no presente artigo, elaborar reflexões sobre os conceitos de representação, simulação e interatividade, além de apresentar alguns jogos, como Sid Meyer's Pirates! (1987), The Secret of Monkey Island (1990), Call of Duty: Black Ops (2010), e Assassin's Creed IV: Black Flag (2013), com a intenção de tornar explícitos os mecanismos de construção da visão de mundo que perpassam por essas produções, as quais articulam narrativa e jogabilidade.

Palavras-chave: videogame; representação; Caribe

\section{Playing with Pirates and Dictators: The representations of the Caribbean in videogames}

Abstract: This article intends to bring to light the way the Caribbean has been represented and simulated in electronic games (Videogames) from 1980 to today. Even though electronic games are today one of the most commercially successful media and have been exerting a strong cultural influence on the construction of a historic imagination, along with other products of the Culture Industry, they are still not used by historians in ample scale, and there is only a small number of research works that consider them as sources. Our goal, in this article, is to elaborate on the concepts of representation, simulation and interactivity, besides presenting games such as Sid Meyer's Pirates! (1987), The Secret of Monkey Island (1990), Call of Duty: Black Ops (2010) and Assassin's Creed IV: Black Flag (2013), as to explicit the world-view producing mechanisms pervading these productions, which articulate narrative and gameplay.

Keywords: Videogame, Representation, Caribbean

Artigo recebido em: 18/02/2016

Artigo aprovado para publicação em: 10/05/2016

\footnotetext{
${ }^{1}$ Mestrando em História Social pelo Programa de Pós-Graduação em História Social da Faculdade de Filosofia e Ciências Humanas da Universidade de São Paulo-USP. Título da pesquisa: O Videogame como Representação Histórica: Narrativa, Espaço e Jogabilidade na série Assassin's Creed (2007-2015). Órgão financiador: Conselho Nacional de Desenvolvimento Científico e Tecnológico (CNPq). E-mail: robsonsbello@gmail.com
}

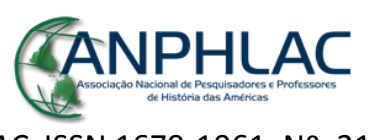

Revista Eletrônica da ANPHLAC, ISSN 1679-1061, №. 21, p. 176-208, Jul./Dez., 2016.

http://revista.anphlac.org.br 


\section{A representação sobre o Caribe}

for in the past winners wrote history; now they are programming and selling it SALVATTI e BULLINGER, 2013

Neste artigo, pretendemos elaborar uma reflexão a respeito das representações históricas construídas sobre o Caribe em uma relativamente nova mídia do entretenimento industrial: os jogos eletrônicos. As relações entre História e Videogame têm sido ignoradas pelos historiadores, apesar do imenso impacto comercial e cultural que eles têm estabelecido nos últimos quarenta anos. Estas relações começaram a ser pontualmente investigadas na última década, mas a produção é ainda muito incipiente. Para além de se estabelecerem como uma nova fonte para os historiadores, os jogos eletrônicos trazem um novo elemento: além de narrarem uma história através de eventos ou processos de longa duração, simulam um espaço onde pode haver interação.

Com isto em mente, propomos refletir sobre como as narrativas que virtualmente reconstituem o Caribe tratam-se, na verdade, de imagens construídas, principalmente pelos países ditos "desenvolvidos", produzidas entre o final do século XX e início do XXI. Diante desse cenário, é preciso que sejam estabelecidos alguns fundamentos teóricos e hipóteses históricas.

Talvez seja possível afirmar que algumas das imagens mais poderosas que vêm a mente quando falamos do "Caribe" sejam praias paradisíacas, oceanos límpidos, céus claros, muito verde, algumas cabanas... e piratas, magia vodu, canibais selvagens, perdidos em algum tempo passado dando lugar à resorts e "ditadores populistas" no século XX. O que aqui abordamos é uma visão de mundo específica e construída, imposta e disseminada sobre o Caribe, simplificando-o e estereotipando-o através de uma indústria produtora e exportadora de bens culturais.

Apesar de não ser possível, neste breve artigo, remontar o processo de construção histórica deste imaginário, esta visão estereotipante remonta há séculos, desde as narrativas de

\section{CANPHLAC}


“viajantes navegantes" a partir do século $\mathrm{XVI}^{2}$. O viajante explorador deu lugar ao colonizador e finalmente a uma indústria do turismo que, através da publicidade, construiu um olhar paradisíaco a milhões de pessoas, e levou milhares de "turistas" ao consumo de seus espaços. No século XX, através da publicidade, mas, sobretudo a partir da indústria cinematográfica, narrativas audiovisuais configuraram que, pela primeira vez na História, representações de uma visão de mundo determinada, que fora produzida historicamente em certos espaços (seja na Europa ou nos Estados Unidos), passassem a circular com a maior intensidade por todo o globo.

Historicamente, a colonização da imaginação, a construção de um determinado imaginário social sobre o Caribe, parece-nos centrada em quadros que se articulam: um paraíso tropical de difícil acesso, distante da "civilização" e permeada de perigos, animais e povos selvagens cuja domesticação é objetivo de criminosos aventureiros, como os piratas, ou forçada por governantes autoritários que manipularam massas débeis. A materialidade disponível, os resorts, são seu contraponto burguês, um oásis higienizado que mantém a natureza intocada e se constitui como uma fortaleza da civilidade.

Esta "terra da aventura", mágica, que torna inumano o humano, tem sua nova expressão nos jogos eletrônicos, cuja particularidade é, para além de narrar, permitir a participação nessa narrativa. Não só a história do Caribe continua a ser contada em seus trajes ahistóricos, como milhões de jovens jogadores são convidados a tomar papeis de colonizadores e domesticadores. Os videogames, além de contarem uma história cuja sequência é temporal (isto é, uma cadeia de acontecimentos linear), passam a simular uma narrativa espacial - uma experiência na qual viajantes virtuais continuam a navegar por um espaço cuja projeção, interpretação e compreensão do outro foi materializada por um Colombo moderno.

Em 2010, a produtora estadunidense Activision lançou o "jogo de tiro"3 Call of Duty: Black Ops, um dos videogames mais vendidos de todos os tempos, contextualizado historicamente logo após a Revolução Cubana, e cuja missão inicial era assassinar Fidel Castro.

\footnotetext{
${ }^{2}$ Com uma proposta não historiográfica, em seu motivador trabalho, A conquista da América: A questão do Outro, Todorov (1983), já apontou como o primeiro deles, Cristovão Colombo, imaginou e reinterpretou o mundo americano e seus habitantes.

${ }^{3}$ Gênero de jogos cujo objetivo é utilizar uma arma de longo alcance e matar inimigos. Representam sobretudo armas de fogo em ambientes fotorrealistas e em primeira pessoa.
}

\section{CANPHLAC}


O site Cubadebate $e^{4}$ posicionou-se a respeito, levantando um debate com psicólogos, produtores e jogadores que vieram em sua defesa. Para o website,

\begin{abstract}
La lógica de este nuevo videojuego es doblemente perversa: por un lado, glorifica los atentados que de manera ilegal planificó el gobierno de los Estados Unidos contra el líder cubano -Fidel ha sobrevivido a más de 600-, y por el otro, estimula actitudes sociópatas de los niños y adolescentes norteamericanos, principales consumidores de estos juegos virtuales. (CUBADEBATE, 2010)
\end{abstract}

Neste artigo, demonstraremos e analisaremos como este e outros jogos eletrônicos perpetuam esta determinada visão de mundo sobre a região do Caribe, reconstituindo os espaços históricos e dando a oportunidade de interatividade a jogadores que, apesar de guardar o potencial de imersão e agência (nos termos de Janet Murray) em uma narrativa que poderia construir empatia, acabam, entretanto, por reforçar seus estereótipos. Analisaremos os jogos estadunidenses Call of Duty: Black Ops (Activision, 2010) e Sid Meyer's Pirates! (Microprose, 1987) e as séries Monkey Island (Lucasarts, 1990-2009) e Tropico (PopTop e Haemimont, 2001-2014). Também, analisaremos o jogo japonês Guevara, traduzido nos Estados Unidos como Guerrila Wars (SNK, 1987), e a série franco-canadense Assassin's Creed (Ubisoft, 20072016).

Vamos analisar, a partir do prisma do protagonismo presente nestes games, as possibilidades de ação do ditador populista e, sobretudo, do pirata - agente da liberdade individual - e como, muitas vezes, enquanto executores da violência e opositores dos "selvagens", ambas as figuras acabam por assemelhar-se.

\title{
2. A especificidade dos games na representação
}

É possível elencar vários exemplos de jogos eletrônicos que são situados no conjunto do Caribe ou localizados em alguns dos países que o compõem. Séries como Tropico (2001, 2003, 2009, 2011 e 2014) e Monkey Island (Lucasarts, 1990, 1992, 1997, 2001 e 2009)

\footnotetext{
${ }^{4}$ Importante site da imprensa cubana organizado por jornalistas cubanos e de outras nacionalidades (há uma versão em Português, por exemplo) cujo principal objetivo é discutir o “terrorismo midiático" contra Cuba. Desde 2007, o site publica as chamadas Reflexiones - textos produzidos por Fidel Castro exclusivamente para o portal.
}

\section{CANPHLAC}


descrevem-se estar na região e se pautam em muitos estereótipos para compor a representação, seja no século XVIII ou durante a Guerra Fria. Os filmes e jogos da série Piratas do Caribe (2001-2011) fazem o mesmo, representando especificamente alguns locais geograficamente precisos (como Port Royal), sendo que o mesmo é feito no icônico Sid Meyer's Pirates (1987). Outros jogos como Sly Cooper and the Thievius Racoonus (2002) e Super Street Fighter II (1993) usam os locais e personagens do Haiti e da Jamaica, respectivamente, como pano de fundo para situações em uma ilha paradisíaca. Cuba aparece em inúmeros jogos de guerra, tanto estratégicos, como os citados "jogos de tiro", como um lugar intrinsecamente povoado pela violência, vividamente representado por jogos como Call of Duty: Black Ops (2010) ou Just Cause (2006).

Os jogos eletrônicos podem representar e simular um passado, permitindo que um jogador (visuais tradicionais discorrem um determinado discurso ideológico, observável pelo interator) efetue ações sobre um espaço imagético que não é tão somente estático (como na pintura) ou móvel (como no cinema), mas sim uma imagem manipulável. É essa característica que permite que o Caribe, dentre outros espaços históricos, possa ser reconstituído virtualmente, podendo contar uma história (storytelling) através de eventos e diálogos de personagens, mas também percorrer e interagir com um determinado ambiente. O discurso ideológico dos jogos eletrônicos é constituído pelas diversas formas de representação, incluindo a composição das cenas, as estruturas narrativas que desenvolvem as tramas e as próprias possibilidades de interatividade.

Se seguirmos as formulações do historiador Roger Chartier, poderemos compreender como as representações sobre o espaço caribenho que aqui discorreremos aspiram a uma pretensa universalidade, isto é, pretendem se construir como discursos neutros que meramente reproduzem a realidade simulada de um Caribe histórico. Entretanto, as representações do mundo social, para o autor, "à revelia dos actores sociais, traduzem as suas posições e interesses objectivamente confrontados e que, paralelamente, descrevem a sociedade como pensam que ela é, ou como gostariam que fosse" (CHARTIER, 1990, p. 19).

Como iremos demonstrar, os jogos eletrônicos descrevem uma realidade histórica precisa: um paraíso tropical selvagem corrompido por inúmeros perigos, os quais o jogador deve superar através da violência e/ou da astúcia. Para o filósofo Douglas Kellner, a "cultura

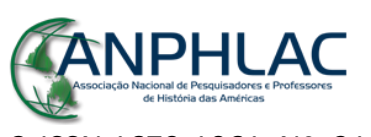

Revista Eletrônica da ANPHLAC, ISSN 1679-1061, №. 21, p. 176-208, Jul./Dez., 2016.

http://revista.anphlac.org.br 
da mídia" é um terreno de disputa entre visões de mundo, uma luta entre representações que reproduziriam os conflitos sociais existentes e transcodificariam os discursos políticos da época e locais determinados em que foram produzidos. Os videogames, como outros produtos culturais, não são simples veículos de uma ideologia dominante nem entretenimento puro e inocente, e sim uma produção social complexa que incorpora discursos políticos e diversas variáveis representacionais. Etnia, raça, classe, sexo, preferência sexual e ideologia são expressas nos termos da organização da sociedade existente e das lutas pelo poder (KELLNER, 2001).

Dessa forma, podemos postular que o jogo histórico é sempre representação. Isto é, sua narrativa, seus espaços, as regras e interações jogáveis possuem determinadas intenções, conscientes ou não, que transformam a História em um objeto interativo cujo objetivo é o entretenimento para consumo de massas. Verificar uma fidelidade ou uma "verdade histórica" presente ou não nestes jogos é um objetivo secundário. De acordo com o historiador Marcos Napolitano (2008), ao analisar produções cinematográficas, muitos historiadores preocupamse com a veracidade histórica dos filmes, o que, embora não seja irrelevante, não constitui o objetivo principal da análise, e apesar de que eventuais anacronismos, omissões e informações devam ser apontados, são apenas parte das preocupações sobre o objeto.

Neste caminho, o historiador do cinema, Eduardo Morettin aponta que há um caráter polissêmico da imagem cinematográfica, em que existe a possibilidade de abrigar leituras opostas, diante da existência de pontos de adesão ou rejeição existentes entre o "projeto ideológico-estético" de um determinado grupo social em imagem (MORETTIN, 2007). A dimensão histórica viria da identificação por meio da análise do discurso em que as obras cinematográficas ou os jogos eletrônicos constroem sobre as sociedades nas quais se inserem.

Entretanto, há um aspecto primordial que diferencia os games de outras mídias e linguagens de representação: os espaços podem ser percorridos e interagidos. Estes ambientes virtuais permitem que jogadores naveguem por um espaço delimitado e interajam de acordo com a proposta e os objetivos das regras do jogo. Os espaços históricos fornecem ao jogador a possibilidade de interação com um passado simulado, mas, na verdade, pretensamente reconstituído que simula a interação em um passado distante.

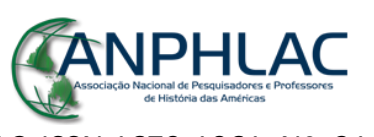

Revista Eletrônica da ANPHLAC, ISSN 1679-1061, №. 21, p. 176-208, Jul./Dez., 2016.

http://revista.anphlac.org.br 
Tais cenários virtuais foram conceituados como uma "narrativa espacial” (spatial story) ou "ambiente-contador-de-histórias" (enviromental storytelling) pelo estudioso de novas mídias, Henry Jenkins, que afirma que os game designers não simplesmente contam uma história, mas sim "desenham mundos" e "esculpem espaços" - e devem ser, portanto, compreendidos como "arquitetos narrativos" (JENKINS, 2002). Esses conceitos nos ajudarão a compreender como os espaços caribenhos em si já transmitem narrativas ao representar signos característicos de representações conformadas dentro da Indústria Cultural, cada vez mais transmidiática, na qual se constroem a partir da autoreferência à cultura da imagem, sobretudo, audiovisual.

Em um momento histórico no qual as representações globalizadas através da Indústria Cultural compõem uma das grandes forças hegemônicas de construção do imaginário, vemos o Caribe imaginado dentro dos games em diálogo constante com os filmes estadunidenses e europeus de grande circulação no tocante à sua representação, mas também resignificando regras lúdicas próprias da linguagem dos jogos eletrônicos, produzindo uma experiência lúdiconarrativa através da manipulação de detalhes do ambiente. A narrativa é construída através do design da geografia deste local imaginado, montado através de obstáculos que criam desafios e possibilidades para o avanço do jogador em direção da resolução do objetivo. A forma de apresentação audiovisual e lúdica do espaço não é neutra: as regras do jogo, o trabalho de câmera, a edição, o som, compõem no todo um filtro narrativo ao ambiente da simulação.

A pesquisadora Janet Murray propõe uma série de conceitos para compreender o papel do jogador dentro das narrativas interativas. Para ela, estas produções pressupõem uma "autoria procedimental", um meio que é construído por um "autor" mas que deve ser interagido por um “interator", cujo papel assume, talvez mais do que no cinema ou na literatura, uma construção ativa do mundo de ilusão à sua frente. A autora desenvolve três princípios fundamentais para estas narrativas: imersão, agência e transformação (MURRAY, 2003).

Essa imersão tem a pretensão de ser a porta de entrada para outro mundo, projetandose em avatares que são outros, acreditando que a agência sobre o espaço pode tanto o transformar quanto o fazer com o próprio participante. Oliver Grau afirma que a imersão

é em muitos casos mentalmente absorvente no desenrolar de um processo, de uma mudança, de uma passagem de um estado mental para outro. Ela é sempre

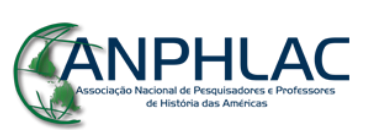

Revista Eletrônica da ANPHLAC, ISSN 1679-1061, №. 21, p. 176-208, Jul./Dez., 2016.

http://revista.anphlac.org.br 
caracterizada pela diminuição da distância crítica do que é exibido e o crescente envolvimento emocional com aquilo que está acontecendo. (GRAU, 2007, p. 30)

Essa pretendida imersão deve ocorrer em espaço interativo, cuja visão de mundo é transmitida através da sua composição audiovisual e das possibilidades de atuação e interação. Este conjunto de representações constitui uma rede de significados dentro da narrativa e dos gameplays, que ao mesmo tempo compõem e são portadores de um sentido ideológico que ajudam a constituir uma determinada visão de mundo e senso de identidade do indivíduo, podendo também contribuir e induzir à identificação, simpatia ou desejo do jogador a certos modos de pensamento e comportamentos.

A "agência" é entendida como participação, uma encenação orquestrada dentro de um espaço navegável. A autora define como agência a "capacidade gratificante de realizarmos ações significativas e ver os resultados de nossas decisões e escolhas" (MURRAY, 2003, p. 127). Seguindo a lógica, quanto mais imersos, mais desejaríamos poder agir sobre aquele universo. Para esta imersão e agência, portanto, há a necessidade dos jogadores serem transformados em avatares, isto é, serem "transmutados" no papel do outro, o qual, na presente discussão, trata-se dos personagens de um Caribe histórico, para então ser exercida uma "agência" sobre este espaço que imergimos e podemos atuar. Para Grau (2007), embora o usuário esteja fora do espaço de imersão dentro da tela do jogo, há uma “conexão lúdica" com as tramas e personagens, impedindo seu distanciamento objetivo. Desta forma, são parte do mundo ao qual investem seu tempo ao intervir de acordo com as regras que constituem e regulam esse espaço virtual.

Veremos agora, portanto, como é possível analisar teoricamente sobre o aspecto propriamente lúdico dos “jogos históricos”.

\section{Jogos Históricos sobre o Caribe}

Devemos definir primeiramente o que chamamos de "jogos históricos" neste trabalho: são games que de alguma forma ("realista" ou não) representam um tempo passado, uma simulação que se situa em algum tempo histórico que já não mais existe, ou que se apropria de elementos deste passado para sua composição. Autores como Kappel e Elliot (2013)

\section{GANPHLAC}


complementam esta perspectiva afirmando que, nestes jogos, nos quais os jogadores podem atuar diretamente ou alterar o resultado de batalhas, campanhas e mesmo civilizações passadas, questões sobre como a história pode ser simulada, recriada e reescrita em uma variedade de níveis, podem surgir novas indagações sobre a relação entre videogames e a História que eles se propõem a representar, diferentes daquelas recorrentes na historiografia tradicional, como questões sobre indeterminação e reconstituição dos espaços em ambientes virtuais.

Para Uricchio (2005), os “jogos históricos” não são um gênero, mas sim um amplo espectro de jogos que brincam com as possibilidades e implicações da representação e simulação histórica, permitindo possibilidades contrafactuais e interação especulativa, e que se constroem a partir de visões e dramas particulares ou teorias de longa duração sobre a História. Ele distingue as "representações", que seriam fixas por natureza, das "simulações", capazes de produzir múltiplos encontros e, portanto, representações especulativas ou condicionais.

Como já mencionado, as próprias regras do jogo importam na compreensão do discurso sobre a realidade histórica representada. O estudioso de games, Gonzalo Frasca, pensa que há três níveis na composição da estrutura dos jogos eletrônicos: 1) o playworld, nível semiótico onde encontramos a representação audiovisual e textual; 2) as regras do jogo, que definem o que o jogador pode, deve, deveria ou não fazer; 3 ) a dimensão do jogar, que seria a manipulação e negociação do jogador com as regras e representações. Estes três níveis se articulam para compor o ambiente virtual explorável e interativo. A escolha das possibilidades, sobretudo das duas primeiras, é um procedimento de escolhas, recortes e ausências por parte dos autores (FRASCA, 2007).

Essas articulações entre narrativa, regras e jogabilidades sempre remetem a um conhecimento e uma representação mais ampla sobre a História, que ultrapassa as fronteiras do próprio jogo e recorre ao imaginário histórico construído tanto educacionalmente, como por filmes, livros e outros produtos da Indústria Cultural. Estes “jogos históricos" sobre o Caribe são reconhecíveis por referenciar imagetica e narrativamente a História construída por todo esse sistema: ao jogar com os piratas em Assassin's Creed IV ou Pirates! há uma lista de filmes, livros e histórias sobre pirataria que os informam; o mesmo ocorre quando o jogador deve lidar com uma "ditadura populista” em Tropico ou Just Cause: já existe uma representação

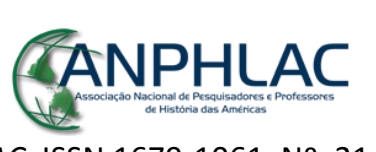


imaginada pré-construída sobre esse período ao jogador, independentemente de quão familiarizado ele seja com o tempo histórico ou a cultura em questão.

Diversos autores e produtores, como o criador de The Sim, Will Wright, ou os realizadores de Assassin's Creed, insistem na ideia de que os jogos não têm como propósito simular a vida real, mas oferecer a possibilidade de jogar, e que a preocupação com a realidade ou a verdade histórica é subordinada ao objetivo maior: o entretenimento. Salvatti e Bullinger postulam o conceito de "autenticidade seletiva", uma série de escolhas feitas pelos produtores para construir um gameplay imersivo, que satisfaz as expectativas da audiência quanto à representação histórica determinada. Não se trata, sobretudo, de estabelecer o que é fato ou ficção, mas sim quais elementos estabelecem uma pretensa autenticidade, e quais estão ausentes (SALVATTI e BULLINGER, 2013).

Há fundamentalmente dois grupos de jogos eletrônicos que representam o Caribe: games que simulam o mundo da pirataria entre os séculos XVII e XVIII e outros que o representam no século XX sobre a ótica da violência e da ditadura. Como iremos observar, esses dois grupos de representação narrativa se articulam com gêneros de jogos específicos: hegemonicamente, a forma de jogar e representar o primeiro grupo é bastante distinto das representações visíveis no segundo grupo. Enquanto os jogos de pirataria envolvem uma “jornada do herói” aventuresca, onde a violência pode fazer parte, mas não é o ponto central, e a astúcia e a exploração do espaço virtual têm primazia; os jogos nos tempos "modernos" explicitamente envolvem a violência banalizada em jogos de tiro, ou uma população passiva aos desmandos do governante nos jogos de estratégia. É importante notar que, de acordo tanto com as leituras feitas quanto com os jogos pesquisados, a sociologia, a antropologia ou a historiografia sobre o Caribe são muito pouco apropriadas e operacionalizadas dentro destes games.

Uma vez abordadas as questões sobre as diferentes representações do Caribe, selecionaremos alguns jogos que são significativos para a exploração dos conceitos e das discussões acima elencados. Ainda que numericamente pouco expressivos, os jogos que representam o Caribe estão entre as produções e as séries cujos rendimentos são recordistas no mundo dos games (Call of Duty: Black Ops e Assassin's Creed), ou ajudaram a estabelecer gêneros e mecânicas lúdicas dentro da indústria (Sid Meyer's Pirates! e Monkey Island), sendo

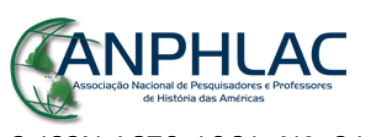

Revista Eletrônica da ANPHLAC, ISSN 1679-1061, №. 21, p. 176-208, Jul./Dez., 2016.

http://revista.anphlac.org.br 
muitas vezes reverenciados pela comunidade gamer ou reconhecidos como games cuja importância simbólica para a indústria não é subestimada. Estes pontos são fundamentais para entender a importância do Caribe dentro da construção da rede de narrativas lúdicas dos games que expressam, por sua vez, um determinado conteúdo representativo sobre a História da região, que atinge circulação global.

Para darmos contas destas questões, estabeleceremos algumas perguntas-chave que orientarão nossa reflexão: 1) De que forma é representado visualmente o Caribe e como seus espaços e habitantes são descritos em termos visuais e dentro das regras dos jogos?; 2) Quais são os papéis e as possibilidades de interação do jogador dentro deste universo e quais seus objetivos dentro da estrutura das regras do jogo?; 3) Qual o significado da representação na articulação entre estas duas dimensões na construção de certas visões de mundo sobre o Caribe?

\section{Os séculos XX e XXI}

A região caribenha aparece ocasionalmente em vários jogos situados nestes séculos, geralmente como uma "fase" única em que irá ser realizada alguma missão específica, ou como cenários e personagens em jogos que figuram representações de várias localidades, como DeeJay e a Jamaica em Super Street Fighter II ou nas West Indies de algumas versões de Ashes Cricket 2009. Entretanto, dois gêneros específicos simulam o espaço de forma mais sintomática e apresentam questões problemáticas que melhor denotam sua representação: os "jogos de tiro", sobretudo em primeira pessoa, que se passam quase exclusivamente em Cuba, e os jogos de estratégia que, a partir de uma ótica moderna, retroagem o processo histórico da "civilização" e incorporam a região como um espaço sem História ou protagonismo.

\section{1. "Jogos de tiro" em Cuba}

É interessante notar que um dos primeiros jogos desenvolvidos sobre a região foi Guerrila Wars (SNK, 1987), nomeado no original japonês simplesmente como Guevara, cujos jogadores controlam avatares de Che Guevara e Fidel Castro e lutam contra um ditador tirânico em ilhas caribenhas. Este é provavelmente um dos únicos jogos que se coloca ao lado de heróis

\section{CANPHLAC}


comunistas, e provavelmente essa é a razão pela qual, quando lançado no ocidente, temendo sentimentos anti-comunistas, o jogo mudou de nome e alterou diálogos e deixou os protagonistas sem um nome definido.

Entretanto, a maioria dos jogos de combate com armas de fogo situados no Caribe se localiza em Cuba e simula um combatente altamente capacitado pronto a assassinar comunistas e ditadores de esquerda. Mencionamos na introdução a polêmica em torno de Call of Duty: Black Ops e o assassinato do sósia de Fidel Castro (Imagem 1), e é interessante pontuar que sua sequência apresenta novas passagens no país. O game tcheco Chameleon (Silver Wish Games, 2005) traz um agente da CIA que, traído, resolve se vingar de assassinos de seus pais em diversos países, inclusive Cuba. A expansão Island Thunder do aclamado "jogo do ano" Tom Clancy's Ghost Recon (Red Storm, 2001) narra uma história na qual, após a morte de Fidel Castro, finalmente o país está "livre" para eleições. Entretanto, um novo grupo político deseja criar um partido único que mantenha o poder. O jogador, como parte de "forças especiais", deve enfrentar este grupo enquanto garante a ordem social e o controle da população.

\section{Imagem 1: Sósia de Fidel Castro sendo acertado com um tiro no rosto}

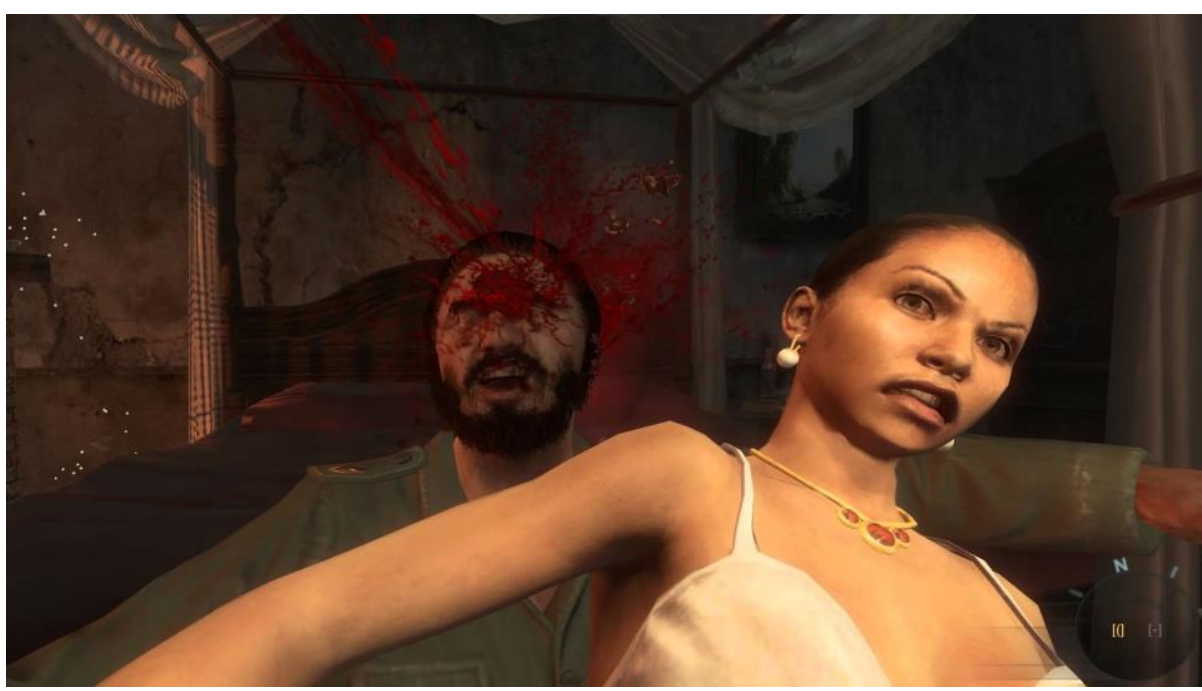

Fonte: https://www.youtube.com/watch?v=Q1JwgHJ1KYU

Bullinger e Salvatti (2013) trabalham com três categorias de autenticidade seletiva para jogos como Call of Duty e Medal of Honor na construção de seu ambiente histórico: o "fetichismo tecnológico" na precisão da representação das armas utilizadas; o uso de

\section{CANPHLAC}


convenções cinemáticas como cenas em estilo documentário e de jornal; e uma autoridade documental através da representação de registros escritos, fotos, mapas e informações precisas sobre o período. Juntas, essas categorias sintetizam o realismo histórico esperado por uma audiência que deseja consumir este tipo de "aventura histórica".

Esse gênero "jogos de tiro" que eventualmente representa Cuba, o Caribe ou até mesmo outros países, deve ser pensado conjuntamente com jogos que representam outros espaços e tempos. Pesquisadores ainda debatem o quanto videogames influenciam um comportamento violento nos indivíduos e não é nosso objetivo adentrar esse aspecto aqui, mas é importante sim, referendar algumas correlações.

Já é conhecido o fato de que estes "jogos de tiro" e outros simuladores de guerra e ambientes de realidade virtual são utilizados pelas forças armadas e policiais em diversos países para o treinamento de seus soldados. O exército americano ajudou a desenvolver a série America's Army e a Naval Special Warfare Command (divisão da marinha estadunidense) trabalhou em colaboração com a produtora Zipper Interactive para o lançamento de SOCOM: U.S. Navy SEALs (Zipper, 2002), e estes são só alguns exemplos de jogos bem sucedidos comercialmente. O objetivo é claro: treinar soldados e potenciais combatentes para ambientes de enfrentamento. Quando "ditadores" e outros inimigos são desumanizados e transformados em obstáculos para o objetivo do jogador, há uma direcionamento ideologico de quem deve, pode - e merece - ser assassinado.

A escolha ideológica das representações é clara: são os inimigos ou traidores dos estadunidenses os alvos a serem combatidos. O produtor Mark Lamia, do jogo Call of Duty: World at War, tenta justificar: "We are making a game, we're not making a political statement" (KELLY, 2008)

Para Bullinger e Salvatti (2013), as representações destes jogos estabelecem fronteiras borradas entre a História "real" e o entretenimento na medida em que a temporalidade histórica é submetida a uma "autenticidade seletiva", que busca a autoridade documental em informações específicas sobre as armas, as fotografias e o ambiente tridimensional "realisticamente" reconstituído. Para os autores, essa seletividade apresenta a História em acordo com os olhares de quem detem o discurso sobre ela, e afirmam que antes os "vencedores do passado escreviam a história, hoje eles a programam e vendem” (BULLINGER E SALVATTI, 2013).

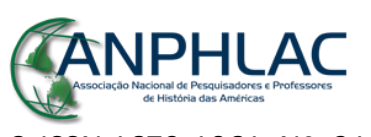




\subsection{Tropico - games de estratégia e o "ditador das bananas"}

Há um certo número de jogos cujo objetivo é construir, planejar e gerenciar estruturas e relações sociais, em pequena e/ou grande escala. São jogos que representam e simulam o processo histórico de civilizações, ou a administração de espaços urbanos e rurais. No jargão comum da indústria dos games, são jogos de "estratégia", mas uma conceituação melhor pode ser definida na ideia de Jogos de Construção e Gerenciamento Social. Quando o Caribe aparece nestes jogos, é geralmente como apêndice, dificilmente figurando qualquer particularidade, seja em sua disposição geográfica ou em culturas locais. Em alguns jogos, povos e regiões mais "populares" da América, sobretudo Central e do Norte, ganham algum destaque. Quando muito, os povos caribenhos aparecem como "primitivos selvagens" e bárbaros aleatórios que frequentam e compõem alguns dos perigos "naturais" da localidade.

Isso tem uma razão de ser. Estes jogos civilizacionais, na verdade, dão vazão a uma leitura teleológica de "avanços" culturais e tecnológicos da História, que, através da conquista imperialista, deixam naturalmente povos "bárbaros" para trás, o que é representado diretamente na dinâmica das regras do jogo. Em resposta às críticas feitas à expansão Colonization do quarto jogo da série Civilization, Steve Martin, presidente da Firaxis Game, coloca a responsabilidade nos jogadores: "As with all previous versions of Civilization, the game does not endorse any particular postion or strategy - players can and should make their own moral judgements" (FRITZ, 2008). Não obstante, retomando a ideia de "autoria procedimental" de Murray, esta série, como tantas outras do mesmo modelo, reifica a experiência histórica colocando os gamers na posição de administradores de um Estado "Moderno" que controla todas suas instituições e busca a acumulação primitiva de capital (simbolicamente representado por reservas naturais de ouro, pedra ou madeira) e a conquista ou defesa de território.

Outro gênero se foca na organização espacial das estruturas e da população interna de uma cidade ou espaço privado. Esse se concentra menos na mobilização de unidades e no levantamento de "recursos", e mais na construção, loteamento e organização espacial das estruturas e das populações que lá habitarão, ou na construção e na organização espacial das

\section{GANPHLAC}


estruturas e das populações que lá frequentarão e gastarão "dinheiro". Um destes jogos é Tropico (PopTop Software, 2001).

Tropico é uma série de games iniciada em 2001, sendo formado por cinco jogos. O último deles, lançado em 2015, Tropico 5, foi desenvolvido para as principais plataformas do período (PC, Mac, Xbox 360, Xbox One e Playstation 4). Nesta série de jogos, que se passam em "ilhas tropicais", o jogador deve tomar o posto de El Presidente, escolhendo ser "Che" Guevara, Fidel Castro e um número de outras figuras históricas ligadas diretamente ao Caribe, para então administrar a ilha e a vida de seus cidadãos. Para tanto, ele deve escolher seu regime de governo (desde permitir eleições a ser explicitamente um ditador opressor), lidar com os vários grupos políticos (comunistas, capitalistas, ambientalistas, militaristas, nacionalistas, etc.) e promulgar leis. Essa simulação da administração de uma cidade/ilha conforma-se à ideia de um Estado sempre presente e voltado ao planejamento urbano, e que tem um modelo de administração que relaciona melhores condições urbanas e acesso à cultura, com possibilidades de ascensão social.

Cada jogo da série desenvolve e incrementa novos modos de jogabilidade à função do líder controlador. Tropico 2: Pirate Cove (Frog City Software, 2003) destoa desse padrão, estabelecendo o jogador como chefe de uma ilha de piratas e criminosos, mas com a mesma jogabilidade e objetivos parecidos. Tropico 3 (Haemimont Games, 2009) retorna à representação original, e Tropico 4 (Haemimont Games, 2011) cria um modo "campanha" em que El Presidente deve recuperar seu poder no Caribe confrontando as maquinações de um líder estadunidense (apesar de também estadunisense, aqui o jogo corrobora a visão anti-imperialista estereotipada). Finalmente, Tropico 5 (Haemimont Games, 2014) desdobra a perpetuação do líder desde a era colonial, passando pelas Guerras Mundiais, a Guerra Fria até os "tempos modernos".

Construído sobre uma representação supostamente sarcástica, irônica e estereotipada, na verdade, a série se apropria e se utiliza destes para reforçar uma ideia de líder ditatorial "populista", recorrente no imaginário da representação sobre o Caribe. A pluralidade política que o jogo aparentemente oferece, na verdade, é uma estrutura reificada de obstáculos, desafios, com os quais o jogador deve se defrontar para garantir o objetivo final: permanecer no poder.

\section{GANPHLAC}


Em jogos de "Gerenciamento", como Age of Empires, Civilization, Caesar e outros que representam a "Civilização" e o Estado ocidental/europeu, a permanência no controle da administração das cidades ou da civilização nunca é questionada (a cidade/civilização pode falir ou ser destruída, mas não há deposição do governante como mecânica de fim de jogo), uma vez que a posição de poder é essencializada e tirada de questão. Entretanto, nesta série, a caricacturização do líder latino-americano como um despótico em potencial tem na própria mecânica do jogo um contexto de compreensão das lideranças que distingue o mundo "civilizado" do "não civilizado": um tem o "direito" por excelência, enquanto o outro deve manipular com o objetivo máximo de perpetuar o poder.

Imagem 2: Quartel General da expansão ${ }^{5}$ Generalíssimo de Tropico 5

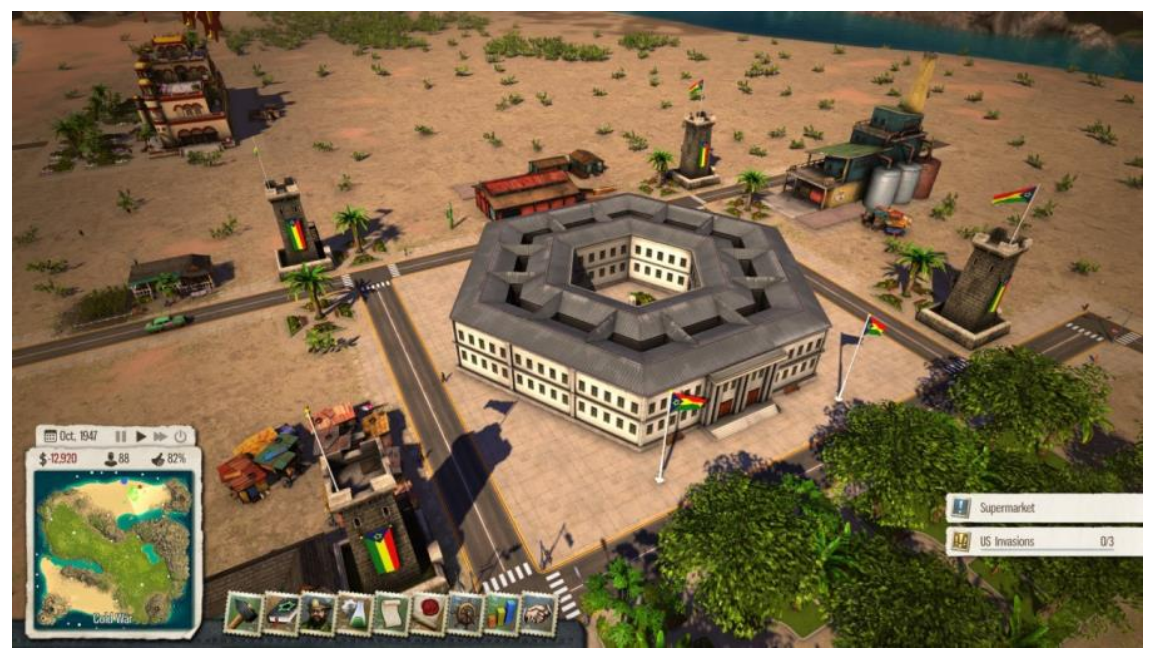

Fonte: http://www.wingamestore.com/product/3694/Tropico-5-Generalissimo-DLC/

Há um avançado debate e visões críticas em relação ao uso do conceito de populismo, principalmente devido à ideia do ditador "populista" ou das "bananas" se articular com diversas produções historiográficas, muitas vezes reducionistas, e filmes satíricos como Brazil ou Bananas. Esse tipo de representação não foi desprezado pela junta militar que estabeleceu uma ditadura na Tailândia em 2014. Meses após sua tomada de poder, o novo governo baniu Tropico 5 afirmando que poderia "afetar a paz e a ordem no país" (GAMASUTRA, 2013). O diretor de

\footnotetext{
${ }^{5}$ Comumente chamadas de Downloadable Contents (DLCs), estas "expansões" são feitas pelos produtores de jogos eletrônicos, sobretudo para jogos de Computador com novo conteúdo variando de novas "fases", personagens, histórias, etc.
}

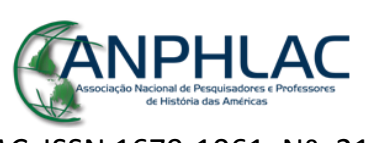

Revista Eletrônica da ANPHLAC, ISSN 1679-1061, №. 21, p. 176-208, Jul./Dez., 2016.

http://revista.anphlac.org.br 
marketing da New Era Thailand, distribuidora do game na região, justificou a restrição afirmando que, "no quinto jogo a história desenvolveu-se além e parte dela pode não ser apropriada na situação atual" do país (GAMASUTRA, 2013). Acreditamos que estas representações e simulações dos games possuem impactos reais e reforçam ideias estereotipadas e visões de mundo. E a forma pela qual agentes reais as interpretam é sintomática da relação dialética entre a representação e aquele que é representado e não deve ser desprezada.

\section{Os Piratas do Caribe nos séculos XVI e XVIII}

Se a representação do Caribe no século XX e XXI é a de ilhas tropicais governadas por tiranos militarescos e manipuladores, de um povo ingênuo, e estão o tempo todo a perigo de serem destituídos ou assassinados, o Caribe "colonial" ou "pré-moderno" desaparece nos jogos de processo civilizacional. Entretanto, este período compõe um gênero de aventura e exploração na pele dos culturalmente eloquentes piratas que são ambiguamente bandidos e heróis. Jogos de pirataria lidam com o controle dos protagonistas piratas em terceira pessoa, que são avatares individualizados estilizados, com distinções comportamentais e personalidades que os diferenciam e contextualizam suas ações em um curso narrativo, como toda uma família de Jogos de Personagem que estabeleceu a fama dos games. Estes jogos apresentam ao jogador a oportunidade de explorar um caribe através da navegação marítima e exploração territorial, mas, em oposição à representação mais contemporânea, seus líderes podem ser bem ou mal intencionados e a população se divide entre colonos, que tentam sobreviver entre os perigos e maus tratos, e nativos, usualmente canibais e selvagens.

Em nossa análise, abordaremos três jogos: Sid Meyer's Pirates, um simulador romantizado da pirataria; Monkey Island, uma aventura voltada à narrativa que satiriza o romantismo pirata; e Assassin's Creed IV: Black Flag, que tem uma pretensão verossímil da reconstituição do Caribe no século XVIII.

\subsection{Sid Meyer's Pirates! e Monkey Island - entre a simulação e a sátira da pirataria.}

\section{GANPHLAC}


Resgatando as narrativas heroicizantes sobre o pirata aventureiro, Pirates! (Micropose, 1987) coloca os jogadores no controle de um jovem marinheiro autorizado pela Coroa espanhola a explorar a região caribenha em busca de fama, glória e riquezas. O espaço navegável inclui a América Central continental, a Península de Yucatán, o Golfo do México e todas as ilhas do Caribe, além das Bermudas. É possível escolher algumas datas de início do jogo $(1560,1600,1620,1640$ e 1660), condicionando o poder de influências dos países europeus dominantes (Espanha, Inglaterra, França e Holanda), dependendo do momento histórico, assim como, os tipos de navios disponíveis.

Dentre as muitas opções de jogabilidade deste game, o jogador pode velejar com um navio, combater outros piratas, saquear tesouros e no remake de 2004 cortejar filhas de governadores da região e batalhar em terra para ocupar cidades. Pirates! foi considerado um importante jogo dentro do desenvolvimento da indústria por permitir um espaço amplamente navegável virtualmente, com eventos programados aleatoriamente, permitindo uma experiência imersiva e divertida.

Kurt D. Squire, ao referendar seu estudo sobre educação em games, afirmou que parte de seu interesse em tecnologia educacional veio de Pirates!, que teria desenvolvido nele, entre outras coisas, "uma profundidade surpreendente no domínio acadêmico", como saber, por exemplo, "a diferença das políticas coloniais em 1580 comparadas com as de 1720" - e, mais importante, ele aponta, que desenvolveu um "gosto" pela História (SQUIRE, 2007, p. 1). Nesse caminho, a discussão sobre a representação nos games, aqui mais especificamente sobre o Caribe, também nos levanta a importante questão sobre qual o potencial do conteúdo educativo dos jogos eletrônicos e o que ele poderia nos informar à respeito do conhecimento histórico.

Pirates! permite conhecer inúmeros dados e fatos sobre os navios, ilhas e alguns personagens da época, e inclusive levanta algum conhecimento enciclopédico. Entretanto, sua representação centra-se na colonização europeia, naturalizando-a, e não problematiza ou complexifica as relações comerciais ou os modos de produção. A escravidão é largamente ignorada e as populações nativas são inexistentes ou adendos silenciosos na composição local. Os "tesouros" e locais estão ali ao conquistador pirata-quixotesco europeu sob o controle do jogador à espera de sua aquisição.

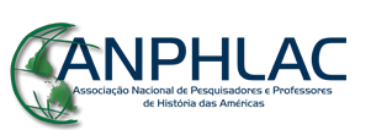


Imagem 3: Navegação no Caribe em Pirates!

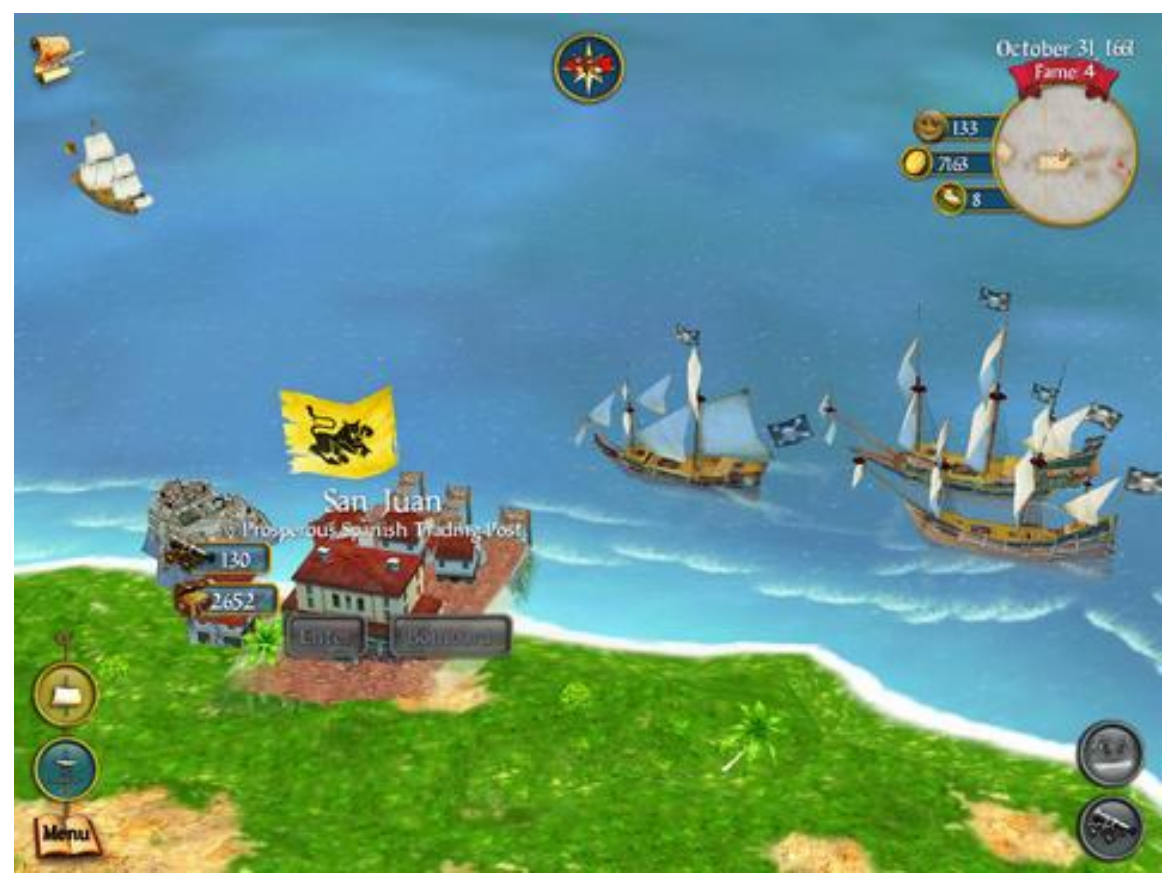

Fonte:https://itunes.apple.com/us/app/sid-meiers-pirates!-for-ipad/id438635005?mt=8

Distintamente de Pirates!, que apresenta um Caribe navegável e cuja principal preocupação é permitir um ambiente virtual em que o jogador possa simular ser um "pirata de verdade", a série Monkey Island é uma aventura que se concentra nos aspectos narrativos, com uma grande concentração de personagens, diálogos e representações satíricas sobre a pirataria e o Caribe. Outra diferença é que, apesar do game anterior ter tido remakes ao longo dos anos, mas nunca ter recebido uma sequência, The Secret of Monkey Island (Lucasfilm Games, 1989) teve quatro continuações, além de dois remakes dos primeiros jogos.

Esta série se localiza no gênero de jogos chamados Point \& Click, onde a solução de enigmas, a storyline e a interação narrativa são seus principais objetivos. Controlando o aspirante à pirata Guybrush Threepwood, o jogador deve conversar com diversos personagens e interagir com o cenário para descobrir "o que fazer" para avançar a narrativa.

A série Monkey Island se passa em um Caribe colonial "modernizado" e místico ao mesmo tempo, cuja frase de apresentação é "No interior profundo do Caribe" ("Deep in the Caribbean”). No primeiro jogo da série, Guybrush deseja se tornar um pirata e para isso deve realizar uma série de quests que representam o que é ser um pirata: caçar um tesouro, tornar-se

\section{CANPHLAC}


um mestre espadachim e roubar a Governadora Elaine Marley, uma mulher autosuficiente, que, em vez de ser resgatada pelo "herói”, tem repetidamente seus planos frustrados por ele, apesar de suas boas intenções. Eventualmente, Guybrush tem de adquirir um navio, encontrar uma tripulação, ir para uma ilha amaldiçoada (a "Ilha dos Macacos") e derrotar o vilão: o fantasma pirata Lechuck. Esta mesma fórmula é repetida nos demais jogos da série, variando os propósito, colocando sempre o jogador a dar cabo do vilão pirata em suas múltiplas formas (fantasma, zumbi, demônio, etc), através da solução de enigmas que envolvem objetos e o cenário.

Sem a preocupação de serem "históricos", os jogos desta série usam elementos que representam a História como um pastiche em um tom cômico em sua montagem e que remetem a um passado místico e fantasioso dentro do Caribe. O universo satírico é composto por piratas, ilhas paradisíacas, animais (sobretudo macacos) selvagens, feitiços vodu e canibais vegetarianos, e recheado de auto-referências à Indústria Cultural, como máquinas de latinhas de grog, letreiros de neon, souvenirs, etc. Particularmente, no quarto título da série, A Fuga da Ilha dos Macacos (Lucasarts, 2000), um empresário Australiano tem o nefasto objetivo de, ironicamente, tornar as ilhas do Caribe em parques temáticos de piratas e resorts.

Imagem 4: Monkey Island II: Lechuck’s Revenge (Lucasarts, 1992)

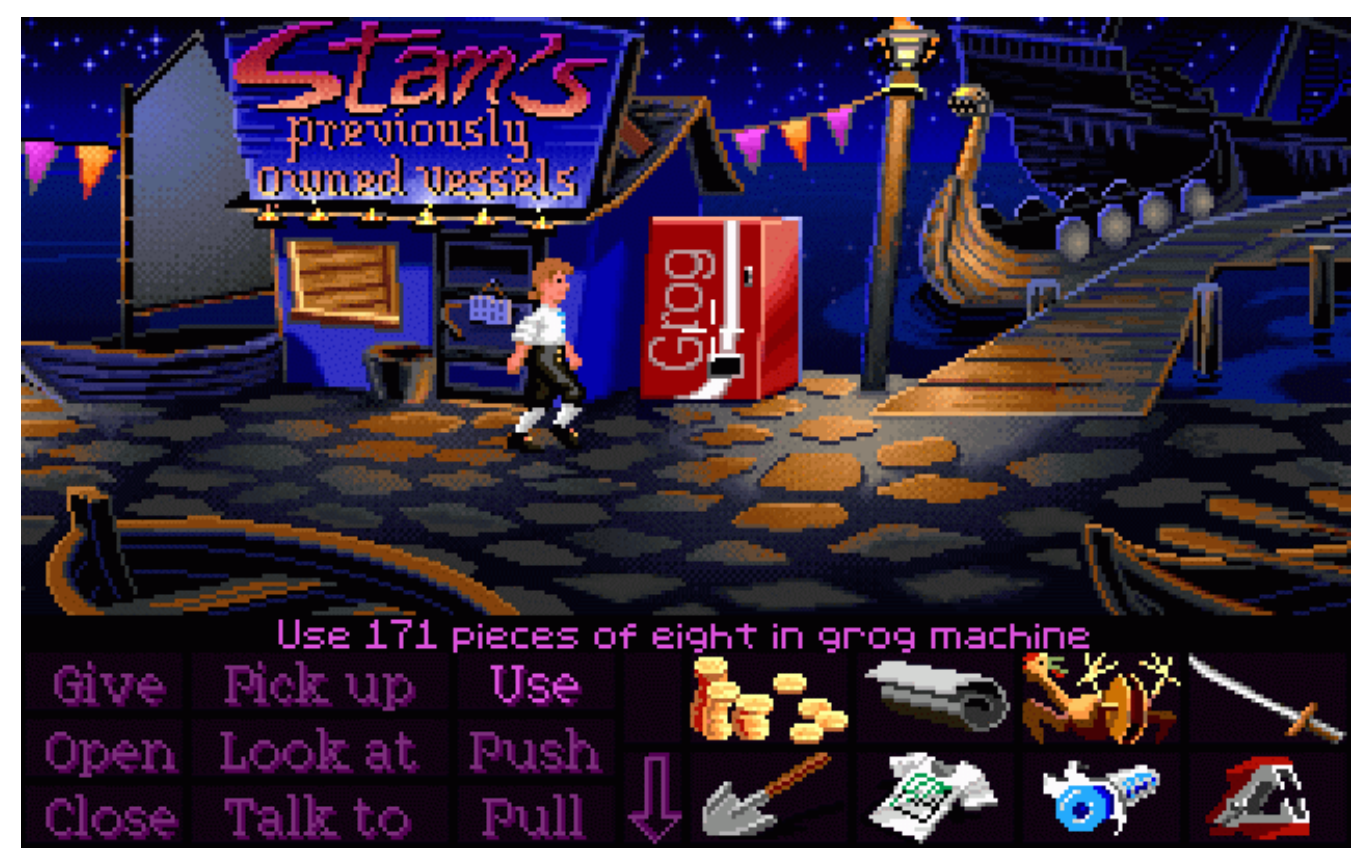

Fonte: http://parchive.org/Monkey-Island-2/Update\%2037/

\section{CANPHLAC}

Revista Eletrônica da ANPHLAC, ISSN 1679-1061, №. 21, p. 176-208, Jul./Dez., 2016.

http://revista.anphlac.org.br 
Alegadamente, tanto Pirates! quanto Monkey Island fizeram apropriações da representação construída sobre a pirataria no brinquedo temático Pirates of the Caribbean, na Disney World, que também teria inspirado o filme homônimo e diversos games da série. $\mathrm{O}$ produtor da Disney, Don Carson, elabora sobre a construção deste espaço: cada textura, som, canto, objeto do cenário deve reforçar a visão socialmente construída sobre o cenário pretendido. Para ele, o elemento da narrativa está infused (infundido) em cada espaço físico que o visitante adentra, que, armado com as "visões coletadas de livros e filmes", está pronto para entrar na aventura. $\mathrm{O}$ truque, para ele, é brincar com estas memórias e expectativas. O reforço do conceito de pirata nesta construção deve vir de "every texture you use, every sound you play, every turn in the road" (CARSON, 2000).

Estas duas séries compõem diferentes gêneros narrativos e lúdicos: Pirates! representa o pirata, enquanto herói romântico, explorador, que balança o coração de donzelas e causa terror em seus inimigos em uma jogabilidade que envolve diversos minigames (modos de jogar distintos), combate e estratégia; Monkey Island satiriza esse herói romântico sem desconstruílo, mas o reforçando, em uma jogabilidade que fomenta a solução de enigmas e o diálogo. Ambas estabeleceram fundamentos para uma miríade de outros games do ponto de vista da jogabilidade e reforçam a representação cultural mais ampla que reifica a pirataria em sua categoria social e seu ideal de liberdade e conquista, distantes de sua consciência histórica que emerge em conflito com o mundo. Os filmes e games da série Piratas do Caribe, em suas diversas edições, desenvolvem-se entre a sátira e o romantismo do mito do pirata. Sua ideologia é a da exploração e conquista de um mundo vazio, parcamente ocupado por europeus já estabelecidos e perigos nativos "naturais" que simplificam, silenciam e desumanizam o processo histórico de conquista do Caribe e da América.

\subsection{Assassin's Creed IV: Black Flag e Freedom Cry - a história "tal como ela foi" e a preocupação multicultural}

Demarcando um distanciamento tanto do pirata heróico quanto do pirata atrapalhado, Assassin's Creed IV: Black Flag voltou a reconstituir uma história de piratas "realista" em sua

\section{CANPHLAC}


suposta "selvageria" e "mundo sujo" por excelência. A série Assassin' Creed vem representando múltiplos tempos históricos, desde seu início, em 2007. Nos jogos anteriores ao que trataremos aqui, a série ambientou-se em reconstituições espaciais e narrativas da Palestina Histórica durante a Terceira Cruzada, das Cidades-Estado Italianas durante a Renascença e das Treze Colônias inglesas durante o processo de Independência dos Estados Unidos.

Inicialmente representado em algumas seções “marítimas” em Assassin's Creed III (Ubisoft, 2012), o Caribe se torna o espaço por excelência em Black Flag ${ }^{6}$. O game nos coloca no papel de um empregado de uma grande corporação do futuro, a Abstergo, que desenvolveu uma máquina capaz de acessar as memórias de um antepassado através da reconstrução genética. Através deste personagem sem nome, rosto ou história definidos, sendo este supostamente o avatar do próprio jogador, passamos a controlar Edward Kenway, um irlandês que vai para as Américas em busca de fama e fortuna. No decorrer de sua história, o personagem interage com figuras históricas, como os piratas Barba Negra e Mary Kid, o governador espanhol Laureano Torres, e participa do conflito histórico do universo ficcional entre Assassinos e Templários, duas organizações que disputam desde tempos imemoriais o futuro da humanidade, esta descendente de uma "Primeira Civilização".

A série Assassin's Creed se destaca não pela qualidade da sua trama ou uma jogabilidade original, mas por pretender ser o maior esforço dentro da indústria dos jogos eletrônicos em representar fidedignamente o passado, sobretudo seus espaços históricos. De fato, o grande chamariz da franquia aos consumidores passou a se tornar "qual" será o próximo local a ser representado. E o esforço disso aparece na série de decisões de design e composição estética que são feitas para representar e reconstituir os espaços e pessoas que neles viviam. Enquanto os jogos anteriores elaboraram sobre cidades como Jerusalém, Florença, Veneza, Roma, Boston, New York, conhecidas pela maior parte do público, ícones da tradição historiográfica ocidental e do mito do progresso histórico, Black Flag se desloca a representar Havana, Port Royal, dentre outras cidades, regiões florestais, inúmeras micro-ilhas habitadas ou não e um vasto oceano.

\footnotetext{
6Um jogo "secundário" da série, lançado para celulares, Assassin's Creed Pirates (2013), vêm a apresentar também o Caribe navegável.
}

\section{GANPHLAC}




\section{Imagem 5: Havana vista por cima}

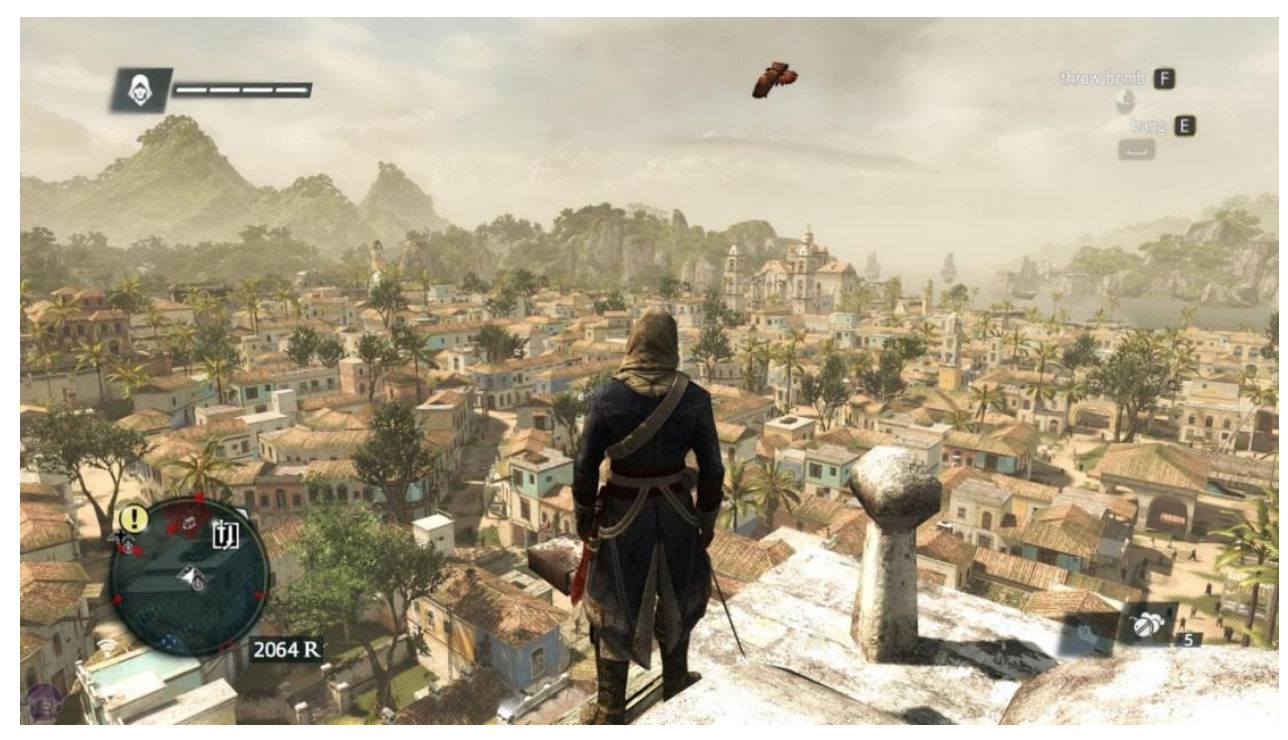

Fonte: http://www.bit-tech.net/gaming/pc/2013/12/03/assassin-s-creed-iv-black-flag-review/1

Isso impacta diretamente em qual história é narrada e o que e como é possível interagir neste espaço e, consequentemente, quais são as leituras históricas possíveis que o distingue dos jogos anteriores da série e dos outros jogos sobre o Caribe e do gênero de pirataria.

Primeiramente, há na representação naturalista um notável esforço em construir uma imersão do jogador neste espaço navegável de um Caribe simulado que o distingue dos traços cartunescos de Pirates! e Monkey Island. Este naturalismo se constitui através da capacidade tecnológica de construir modelos poligonais de pessoas e locais que se assemelham ao "real", criando uma esfera de ilusão. Ilusão esta que está no próprio fundamento do conceito de lúdico trabalhado por Johan Huizinga que resgata seu enraizamento no conceito de iludere, isto é, produzir uma ilusão: a ilusão e a concretude real das regras do jogo estimulam um não distanciamento neste ambiente digital entre o simulado e o possível, a brincadeira e o realizável.

O avatar do protagonista, um habilidoso pirata e assassino, é capaz de correr, saltar, nadar, escalar, combater com exímia maestria, permitindo que ele explore cavernas, rochedos, montanhas, florestas, construções e o próprio fundo do oceano. Este "passe livre" para a exploração do espaço é codificado a partir de regras que também o limitam, estabelecendo o "realismo" da simulação: é possível ser morto, machucar ao cair, afogar-se, etc. Do ponto de vista da reconstituição histórica, apesar da pequena existência de plantas (desenhos arquitetônicos) e outros documentos sobres as cidades caribenhas no século XVIII, os

\section{CRANPHLAC}


produtores arquitetaram um espaço onde ruas, casas populares e edifícios históricos convivem para sua exploração.

Isso reverbera na própria concepção da jogabilidade inovadora, de controle e combate com navios, que diferente do estabelecido por Pirates!, o faz sob uma visão que não é topográfica (lembrando um tabuleiro), mas a partir de uma câmera que acompanha o avatar principal e, portanto, as batalhas ocorrem a partir da perspectiva de dentro do navio e é possível, a qualquer momento, largar sua direção e ir observar qualquer ilha ou atracar e invadir outra embarcação.

Imagem 6: Navegando pelo Caribe em Black Flag

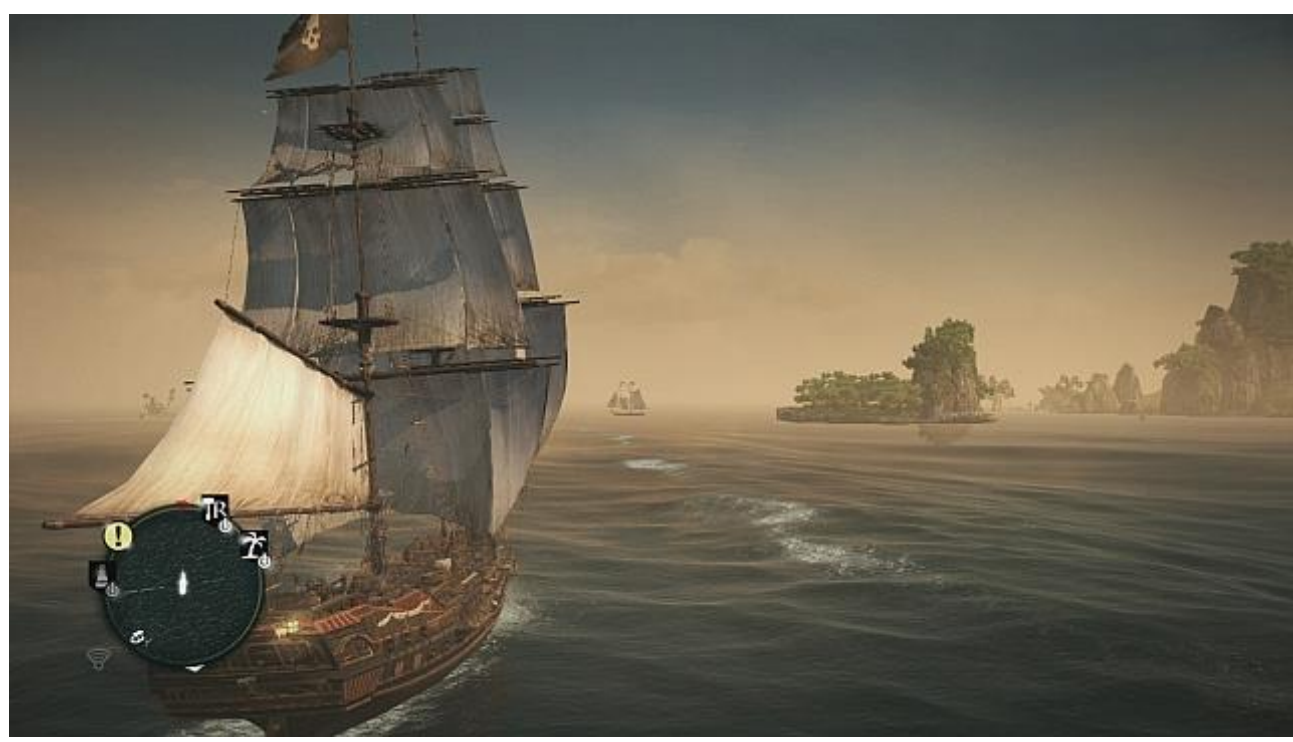

Fonte: http://www.bdplay.com/gaming-world/assassins-creed-iv-black-flag-game-review-video-screenshots

Já no tocante à narrativa e a representação audiovisual, construídas stricto sensu, Edward Kenway é um pirata romântico que vai a busca de fortuna, mas durante o decorrer da história percebe que abandonou todos que importavam para ele, viu muita violência e crueldade desnecessárias e eventualmente procura transcender sua busca material. Isto acontece quando se associa com os Assassinos, lutadores da "liberdade", que enfrentam os Templários, uma organização descendente dos Cavaleiros Templários das Cruzadas, e que, assim como outras narrativas sobre "teoria da conspiração", articulam uma dominação mundial através da "ordem" e do "controle". Em sua jornada, Kenway encontra um grande leque de personagens que

\section{CANPHLAC}


incluem locais, negros, mestiços, travestis, os quais não são reduzidos a estereótipos, mas compõem personalidades complexas e fundamentais à trama. Apesar de não ser ponto-chave da trama, o tráfico negreiro e a instituição da escravidão são explicitados, problematizados e criticados tanto por Assassinos quanto por Templários, relegando o papel de escravistas à senhores de escravos que impediriam o progresso humano.

Esse conjunto de representações pode ser pensado dentro de uma lógica própria da produção da série, que capitaliza sobre a História, para construir um determinado pacote ideológico a fim de agradar seus consumidores. A representação "multicultural” expressa um posicionamento político de valorização da representatividade de "minorias sociais" que vem sendo adotado desde o primeiro Assassin's Creed e que refuta a idealização e misticismo de um passado sem conflitos sociais. Entretanto, não é a toa que em quase todos os jogos (com exceção de Assassin's Creed III: Liberation e a expansão de Black Flag, nomeada Freedom Cry), o protagonista é "embranquecido" ou estritamente um europeu masculino, que em sua posição privilegiada e esclarecida vê o sofrimento do mundo ao seu redor e luta contra suas injustiças. A teoria que alimenta esta ideia centra-se em uma História construída e movida por indivíduos cuja excepcionalidade faz transcorrer seu curso e este é o papel do protagonista que, "conscientizado" pela necessidade do "bem maior", luta contra o controle das liberdades individuais defendida pelos Assassinos.

Há, portanto, uma construção que desloca a perspectiva social e política, os interesses e conflitos entre agentes, os Estados e o desenvolvimento da acumulação de capitais na exploração da terra e dos povos, fossem estes americanos ou africanos. A pirataria é fruto de iniciativa individual, a escravidão, um desvio moral, perpetrada por conservadores racistas com pouca ou nenhuma relação com um projeto colonialista e racial mais amplo. O mecanismo narrativo de acessar as memórias do antepassado para descobrir seus segredos é uma Historia Magistra Vitae: o presente alienado e desprendido de seu passado (exótico) volta-se a ele para tirar lições, e assim guiar e controlar o futuro. Este fundamento da historiografia europeia do século XIX, que orientou suas relações neocolonialistas, tem prosseguimento na perspectiva dos produtores em representar "fielmente" a História destes jogos, ambiguamente discursando na fala de personagens e dos próprios produtores, que afirmam que “em Assassin's Creed a

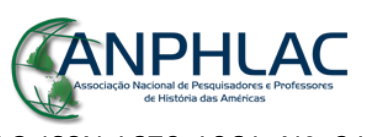

Revista Eletrônica da ANPHLAC, ISSN 1679-1061, №. 21, p. 176-208, Jul./Dez., 2016.

http://revista.anphlac.org.br 
História é o playground" (KAPPEL e ELLIOTE, 2013), e na busca pela autenticidade e pelo passado tal como ele foi.

\subsection{Assassin's Creed IV: Black Flag - Freedom Cry-a revolta no Haiti em 1934}

Alguns meses após o lançamento de Assassin's Creed IV: Black Flag, a produtora Ubisoft anunciou uma expansão a ser baixada pela internet chamada Freedom Cry, cujo protagonista iria ser Adéwale, um membro negro dos Assassinos e um dos aliados de Edward Kenway no jogo original, e cujo tema seria a "luta contra a escravidão". O diretor de arte, Raphael Lacoste, afirma que ficou muito empolgado quando viu os primeiros conceitos sobre o personagem, cuja motivação seria sobre a vingança. Para ele, "You feel the presence and terrible consequences of slavery. Adéwale is able to free a lot of people. He symbolizes their frustration, their anger, and their sadness" (MILLER, 2015). No papel deste novo assassino, o jogador pode percorrer uma área menor (em torno da ilha do Haiti e São Domingos), capturando e libertando navios negreiros, invadir e liberar escravos de plantations, ou de situações de açoitamento em meio a cidade. Narrativamente situado em 1734, o protagonista se vê imerso nas revoltas quilombolas na região e deve auxiliá-los rumo a seu sucesso, aliando-se a figuras como Bastienne Josèphe e Augustin Diefort em Port-au-Prince.

Imagem 7: Bastienne Josèphe e Adéwale

\section{GANPHLAC}




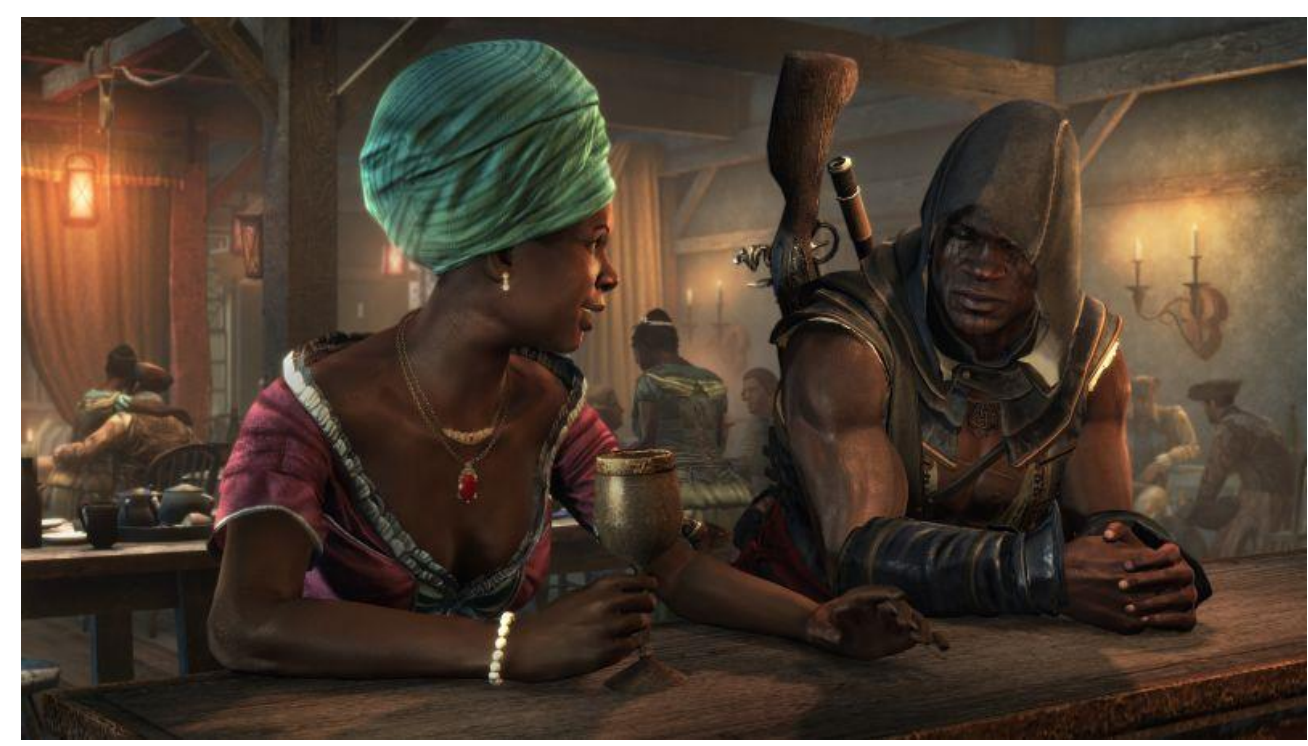

Fonte: http://kotaku.com/a-game-that-showed-me-my-own-black-history-1486643518

Anteriormente, Assassin's Creed III: Liberation (2012) havia trazido Aveline de Grandpré, uma assassina negra, filha de um "lorde" francês e uma liberta, entretanto, é um dado facilmente verificável que protagonistas de descendência africana que incorporam e representam a identidade negra são quase inexistentes nos jogos eletrônicos, assim como representações que ultrapassam o "cenário de fundo" sobre a escravidão. Neste sentido, a proposta "multicultural" de Assassin's Creed, que equaliza universalmente todos sobre a História eurocêntrica, assume um papel positivo, de acordo com o crítico Evan Narcisse em um artigo que nomeou A Game that showed me my black history (NARCISE, 2014). Ele se questiona se "Freedom Cry enfraquece os horrores históricos do Comércio Triângular os usando como entretenimento" (NARCISE, 2014) e responde que não e acredita que o terror da escravidão deve ser sim trabalhado por produtos da indústria pop.

Para Narcisse, o jogo foi capaz de trazer a brutal história negra da diáspora haitiana e das comunidades quilombolas que resistiram à escravidão no período sem os estereotipar e construindo conexões com seus descendentes no presente. Na posição de um "herói que liberta escravos", a violência e os discursos raciais que transformaram povos em mercadorias são explicitados, mas poucas vezes um game teria trazido "empoderamento" e representatividade para a questão da negritude como Freedom Cry.

\section{CANPHLAC}


Entretanto, o crítico pontua algumas questões que nos são interessantes do ponto de vista da representação histórica. Ele ressalta o caráter "repetitivo" das missões e eventos e como o protagonista em sua incrível mobilidade salva pessoas brutalizadas pela escravidão, cuja paciência é "superhumana", que são salvos e conduzidos através de frases como "You deserve a choice" e "Trust Yourself". Como já trabalhamos acima, esta é a jornada de um protagonista esclarecido que realiza sua excepcionalidade conduzindo a História e salvando pessoas “comuns". A libertação dos escravos viria do acompanhamento da própria libertação enquanto indivíduo, de possuir uma escolha e confiar em si mesmo.

O mecanismo de repetição, entretanto, lembra-nos que não é a individualização de um agente escravizado que desaparece na massa violentada, mas a massificação da individualização como realização pessoal. A repetição do salvamento pelo protagonista parte das "regras do jogo", torna a libertação dos escravos uma "tarefa" que lhe rende benefícios (pontos de jogo) e a realização da brutalidade diminuída. A crítica moral precisada no caráter do senhor de escravo, é feita de uma distância segura de quem não tem mais nada a ver com isso, projetando a pessoas "imorais" no passado a execução de um racismo planejado, que não faz parte de um determinado modo racial de ver o mundo, que se perpetua por outras vias até hoje. Da mesma forma, a agência dos movimentos de resistência, negociação e luta dos escravizados quilombolas é negada ou ao menos diminuída frente à sua dependência de um "herói", controlado pelo jogador e que "esclarecidamente" salva tudo e todos.

Não obstante, concordamos com Narcisse quanto à importância, diríamos até a necessidade, da representação sobre a escravidão, tornando visível a uma legião de jovens consumidores a brutalidade que sofreram africanos escravizados, indígenas massacrados e quaisquer outros povos oprimidos. Entretanto, o que aqui evidenciamos é a natureza desta representação e simulação articulada, especificamente nos videogames, a uma jogabilidade que serializa o sofrimento em prol do entretenimento. Um evento único na narrativa do game é o momento de uma libertação de um navio negreiro roteirizado, isto é (não segue as regras da repetição do jogável), quando, ao tentar salvar pessoas de uma embarcação, ela é afundada por outra com a intenção de assassinar os homens e mulheres ali capturados, impedindo sua fuga com o navio de Adewale. O que se segue é uma das cenas mais brutais dentro da Indústria Cultural: o tormento do jogador em tentar salvá-los, e falhar, enquanto o navio afunda. $\mathrm{O}$

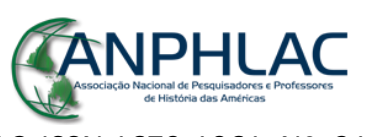

Revista Eletrônica da ANPHLAC, ISSN 1679-1061, №. 21, p. 176-208, Jul./Dez., 2016.

http://revista.anphlac.org.br 
resultado é uma pilha de corpos flutuando enquanto Adéwale escapa. Este momento em específico articula a narrativa (o navio sendo bombardeado) e a jogabilidade (o jogador tentando ineficazmente salvar os presos) em uma tensão que levanta o horror sobre aquele sistema desumano.

Imagem 8: Adéwale escapando do navio em meio aos corpos

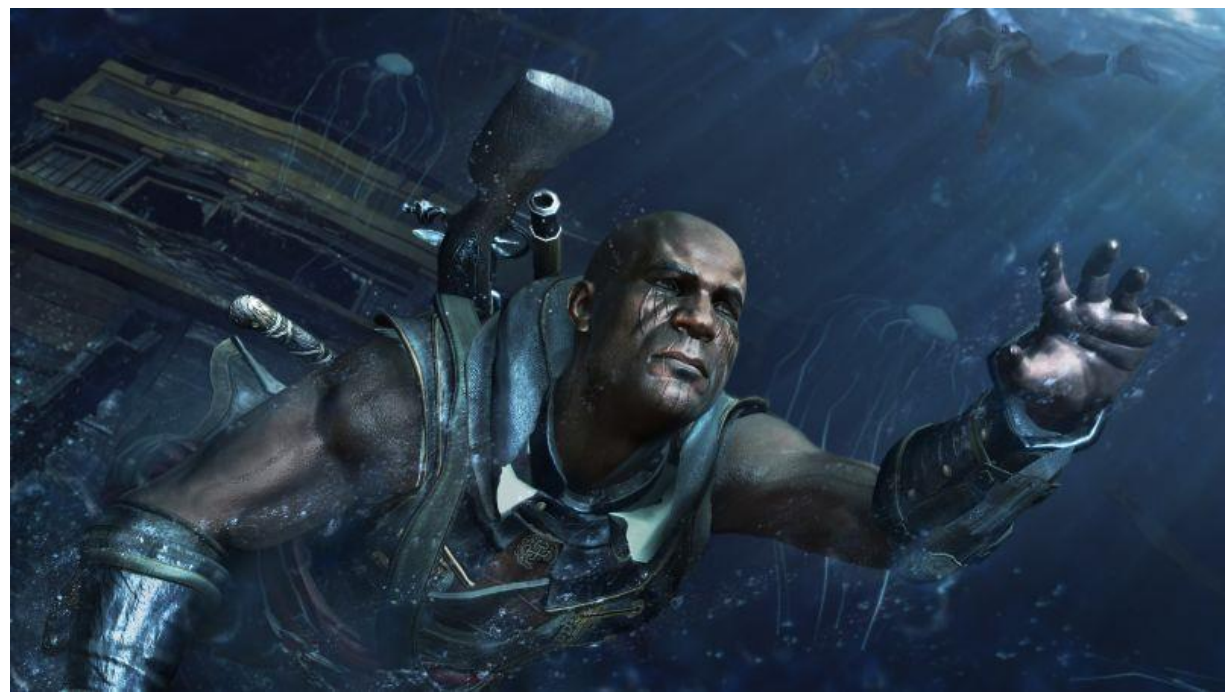

Fonte: http://kotaku.com/a-game-that-showed-me-my-own-black-history-1486643518

\section{Considerações Finais}

Como tentamos demonstrar neste artigo, a indústria dos games tem se utilizado recorrentemente de representações históricas sobre o Caribe, e o que vemos em sua grande maioria são aparições estereotipadas e que reproduzem uma visão colonialista sobre seus povos, espaços e História.

Como pudemos observar, as aparições do Caribe no século XX e XXI restringem-se a cenários paradisíacos ocupados por “ditadores populistas”, que podem ser controlados em jogos como Tropico, ou devem ser exterminados, como em Call of Duty e Just Cause. Já os jogos em que um Caribe "pré-moderno" é representado, o mesmo cenário paradisíaco é espaço do embate entre colonizadores aventureiros e um mundo selvagem e místico, povoado por perigos "naturais". Mesmo Assassin's Creed IV: Black Flag e Freedom Cry, em sua preocupação

\section{GANPHLAC}


"multicultural", estabelecem-se sobre narrativas cujos fundamentos estão em preceitos da historiografia eurocêntrica, ainda que colaborem para a construção de alternativas.

Os jogos eletrônicos são hoje produtos de intenso consumo e lucro para produtoras e expressam determinadas representações e visões de mundo, em uma simulação interativa, que não devem ser desprezadas pelo historiador ou qualquer um que se interesse em pensar a sociedade hoje, pois constituem um vetor que muitas vezes é considerado "educativo". É possível encontrar na internet uma série de imagens e textos feitos por jogadores que procuram legitimar seu consumo destes jogos em relação ao potencial de seu aprendizado.

Faz-se necessário, portanto, maiores estudos dos historiadores e demais cientistas sociais em investigar este aparato indústrial e ideológico, que dialoga e muito com Hollywood, seja no tocante ao Caribe ou outros espaços sociais e históricos, para compreender quais são suas construções ideológicas e possibilidades de apropriação, e diante da sua inserção social em crescimento, estabelecer um contraponto crítico que compreenda como esta nova mídia funciona.

\section{Referências Bibliográficas}

CARSON, D. Environmental Storytelling: Creating Immersive 3D Worlds using Lessons learned from the Theme Park Industry. Gamasutra.com. Disponível em: http://www.gamasutra.com/features/2000301/carson_pfv.htm Acessado em: 21/04/2013

CHARTIER, R. A História Cultural. Entre Práticas e Representações. Lisboa, DIFEL: 1990.

FRASCA, G. Play the Message: Play, Game and Videogame Rhetoric. 2007. 213 f. Tese (Doutorado em Filosofia). IT University of Copenhagen, Copenhagen. 2007

GRAU, O. Arte Virtual da ilusão à imersão. São Paulo: Editora UNESP: Editora SENAC São Paulo, 2007.

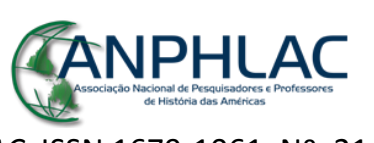

Revista Eletrônica da ANPHLAC, ISSN 1679-1061, №. 21, p. 176-208, Jul./Dez., 2016.

http://revista.anphlac.org.br 
JENKINS, H. Game Design as Narrative Architecture. In: WARDRIP-FRUIN, N.; HARRIGAN, P. (Orgs.). First Person: New Media as Story, Performance and Game. Cambridge, MA; London, England: MIT, 2002.

KAPPELL, M. W.; ELliOT, A. B. R. (Orgs.). Playing with the Past. Digital Games and the Simulation of History. New York: Bloomsbury, 2013.

KELLNER, D. A Cultura da Mídia. Bauru: Edusc, 2001.

KELLY, K. Joystick Interviews Mark Lamia of Treyarch and Call of Duty the Fifth. In: Joystick. Disponível em: https://www.engadget.com/2008/06/24/joystiq-interviews-marklamia-of-treyarch-and-call-of-duty-the-f/. Acessado em 24 de Junho de 2013

MILLER, M. Assassin's Creed - The Complete Visual History. Insight Editions, San Rafael, California: 2015

MORETTIN, E. O cinema como fonte histórica na obra de Marc Ferro. In: CAPELATO, Maria Helena R. et. al. (Orgs.). História e Cinema. São Paulo, Alameda, 2007.

MURRAY, Janet H. Hamlet no Holodeck: O futuro da narrativa no ciberespaço. São Paulo: Unesp, 2003.

NAPOLITANO, M. A História depois do Papel. In: PINSKY, Carla Bassanezi (Org.). Fontes Históricas. $2^{\mathrm{a}}$ ed., São Paulo: Contexto, 2008.

SAlVATI, A. J.; BULlingER, J. M. Selective Authenticity and the Playable Past. In: KAPPELL, Mathew Wilhelm; ELLIOT, Andrew B. R. (Orgs.). Playing with the Past. Digital Games and the Simulation of History. New York: Bloomsbury, 2013.

SQUIRE, K. Games, Learning and Society: Building a Field. In: Education Technology. September-October, 2007.

TODOROV, T. A Conquista da América. A Questão do Outro. São Paulo: Martins Fontes, 1983.

\section{SITES DA INTERNET}

CUBADEBATE. Nueva Operacion contra Cuba. EEUU lanza videojuego cuyo objetivo es asesinar a Fidel.

Disponível em: http://www.cubadebate.cu/noticias/2010/11/09/nueva-operacion-contra-cubaeeuu-lanza-videojuego-cuyo-objetivo-es-asesinar-a-fidel/

Acessado em: 05/01/2016

FRITZ, BEN. Firaxis responds to my Colonization Post. The Cut Scene - Video Games Blog on Variety.com. 2008

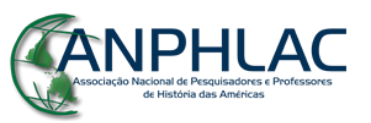

Revista Eletrônica da ANPHLAC, ISSN 1679-1061, №. 21, p. 176-208, Jul./Dez., 2016.

http://revista.anphlac.org.br 


\section{GANPHLAC}

Revista Eletrônica da ANPHLAC, ISSN 1679-1061, №. 21, p. 176-208, Jul./Dez., 2016.

http://revista.anphlac.org.br 
Disponível em:

http://web.archive.org/web/20100930155207/http://weblogs.variety.com/the_cut_scene/2008/ 06/firaxis-respond.html.

Acessado em: 05/01/2016

Tropico 5: banned in Thailand, as it 'might affect peace and order. Gamasutra.com

Disponível

em:

http://www.gamasutra.com/view/news/222522/Tropico_5_banned_in_Thailand_as_it_might_ affect_peace_and_order.php

Acessado em: 05/01/2016

NARCISE, E. A game that showed me my black history. Kotaku.com.

Disponível em: http://kotaku.com/a-game-that-showed-me-my-own-black-history1486643518

Acessado em: 20/11/2015

\section{JOGOS CITADOS}

Assassin's Creed IV: Black Flag (Ubisoft, 2013)

Call of Duty: Black Ops (Activision, 2010)

Chameleon (Silver Wish Games, 2005)

Guevara (SNK, 1987)

Just Cause (Eidos, 2006)

Tom Clancy's Ghost Recon (Red Storm, 2001)

The Secret of Monkey Island (Lucasfilm Games, 1990)

Tropico (PopTop Software, 2001)

Tropico 2: Pirate Cove (Frog City Software, 2003)

Tropico 3 (Haemimont Games, 2009)

Tropico 4 (Haemimont Games, 2011)

Tropico 5 (Haemimont Games, 2014)

Sid Meyer's Pirates (Micropose, 1987)

Super Street Fighter II (Capcom, 1993) 